\title{
Growth and nitrogen removal characteristics of Halomonas sp. B01 under high salinity
}

\author{
Te Wang $^{1,2}$ (I) $\cdot$ Zhengzhong Jiang $^{1} \cdot$ Wenbo Dong $^{1} \cdot$ Xiaoya Liang $^{1} \cdot$ Linghua Zhang $^{1} \cdot$ Yimin Zhu $^{1}$
}

Received: 25 July 2019 / Accepted: 3 November 2019/Published online: 18 November 2019

(C) The Author(s) 2019

\begin{abstract}
Purpose At present, the nitrogen $(\mathrm{N})$ removal efficiency of the microbial treatment in the high-salinity nitrogenous wastewaters is relatively low. Study on the N removal behavior and properties of moderately halophilic bacteria Halomonas under high salinity is of great significance for the microbial treatment of high-salinity nitrogenous wastewater.

Methods The response mechanism of Halomonas sp. B01 to high osmotic pressure stress was investigated by measuring the compatible solute ectoine concentration and superoxide dismutase (SOD) activity. The salt tolerance during growth and $\mathrm{N}$ removal of the strain was evaluated by measuring the activities of growth-related and $\mathrm{N}$ removal-related enzymes and the mRNA expression abundance of ammonia monooxygenase-encoding gene ( $a m o A)$. The process of simultaneous heterotrophic nitrification and aerobic denitrification (SND) under high salinity was described by measuring the concentration of inorganic $\mathrm{N}$. Result Halomonas sp. B01 synthesized ectoine under $\mathrm{NaCl}$ stress, and the intracellular ectoine concentration increased with increased $\mathrm{NaCl}$ concentration in the growth medium. When the $\mathrm{NaCl}$ concentration of the medium reached $120 \mathrm{~g} \mathrm{~L}^{-1}$, the malondialdehyde concentration and SOD activity were significantly increased to $576.1 \mu \mathrm{g} \mathrm{mg}^{-1}$ and $1.7 \mathrm{U} \mathrm{mg}^{-1}$, respectively. The growth-related and $\mathrm{N}$ removal-related enzymes of the strain were active or most active in medium with $30-60 \mathrm{~g} \mathrm{~L}^{-1} \mathrm{NaCl}$. The amoA of the strain cultured in medium with $60 \mathrm{~g} \mathrm{~L}^{-1} \mathrm{NaCl}$ had the highest mRNA expression abundance. In the $\mathrm{N}$ removal medium containing $60 \mathrm{~g} \mathrm{~L}^{-1} \mathrm{NaCl}$ and $2121 \mathrm{mg} \mathrm{L}^{-1} \mathrm{NH}_{4}{ }^{+}-\mathrm{N}$, SND by Halomonas sp. B01 was performed over $96 \mathrm{~h}$ and the $\mathrm{N}$ removal rate reached $98.8 \%$.

Conclusion In addition to the protective mechanism of synthetic compatible solutes, Halomonas sp. B01 had the repair mechanism of SOD for lipid peroxidation. The growth-related and N removal-related enzymes of the strain were most active at a certain salt concentration; amoA also had the highest mRNA expression abundance under high salinity. Halomonas sp. B01 could efficiently perform $\mathrm{N}$ removal by SND under high salinity.
\end{abstract}

Keywords Halomonas $\cdot$ High salinity $\cdot$ Salt tolerance $\cdot$ Nitrogen removal

\section{Introduction}

Simultaneous heterotrophic nitrification (SND) and aerobic denitrification constitute a nitrogen $(\mathrm{N})$ removal method in which nitrification and denitrification are performed simultaneously in the same reaction system with a supplied organic carbon source and oxygen. SND has advantages such as fast

Linghua Zhang

dlzlh2008@163.com

1 Environmental Science and Engineering College, Dalian Maritime University, 1 Linghai Road, Dalian 116026, China

2 Liaoning Institute of Science and Technology, 176 Xianghuai Road, Benxi 117004, China microbial growth, self-adjusting $\mathrm{pH}$ balance in the $\mathrm{N}$ removal system, simple processing mechanisms, and high $\mathrm{N}$ removal efficiency (Shoda 2017). Some industries generate highsalinity nitrogenous wastewater, such as those undertaking leather processing and marine aquaculture; using synthetic ammonia and chemical fertilizer; maintaining landfills; and producing nickel batteries. The $\mathrm{N}$ removal efficiency of the microbial treatment, especially that of SND processes, in these high-salinity nitrogenous wastewaters is relatively low. The main reason is that high salinity levels inhibit microbial growth and metabolic activity. Therefore, theoretical and technical research on SND in high-salinity nitrogenous wastewater is of great significance. Research on $\mathrm{N}$ removal by moderately halophilic bacteria from high-salinity nitrogenous wastewater has been of interest in recent years. In the family 
Halomonadaceae, Halomonas is a genus of moderately halophilic bacteria that currently includes 79 species (de la Haba et al. 2014). Some of these strains have been reported to be capable of nitrification, denitrification, or simultaneous nitrification and denitrification at certain salt concentrations (Berendes et al. 1996; Mormile et al. 1999; Guo et al. 2013; Wang et al. 2017). Te Wang reported that Halomonas sp. B01 can simultaneously tolerate high concentrations of both $\mathrm{NaCl}$ and $\mathrm{NH}_{4}{ }^{+}-\mathrm{N}$ and efficiently perform SND. In a $\mathrm{N}$ removal solution containing $60 \mathrm{~g} \mathrm{~L}^{-1} \mathrm{NaCl}$ and $4000 \mathrm{mg} \mathrm{L}^{-1} \mathrm{NH}_{4}{ }^{+}$$\mathrm{N}$, SND was performed over $180 \mathrm{~h}$ under optimal conditions and resulted in a residual total inorganic $\mathrm{N}$ concentration of $21.7 \mathrm{mg} \mathrm{L}^{-1}$, and the $\mathrm{N}$ removal rate reached $99.2 \%$ (Wang et al. 2017). Halomonas spp. show unique potential in the treatment of wastewater with respect to $\mathrm{N}$ removal. In addition to their strong growth and metabolism and $\mathrm{N}$ removal while significantly reducing the COD of wastewater, the most notable feature is their resistance to high salinity growth and $\mathrm{N}$ removal.

It is of great theoretical and practical significance to study the resistance of Halomonas bacteria to high salinity growth and $\mathrm{N}$ removal. Most Halomonas bacteria can resist environmental osmotic stress by synthesizing compatible solute ectoine (1,4,5,6-tetrahydro-2-methyl-4-pyrimidinecarboxylic acid) (Pastor et al. 2010). However, neither lipid peroxidation caused by high salinity nor a superoxide dismutase (SOD) repair mechanism has been reported for Halomonas. Numerous studies have described Halomonas growth (including reports of the optimal salt concentration for growth) and ectoine synthesis of different strains of Halomonas in different $\mathrm{NaCl}$ concentrations (de la Haba et al. 2014; Yin et al. 2015), but the relationship between the activities of growth-related and $\mathrm{N}$ removal-related enzymes in Halomonas and $\mathrm{NaCl}$ concentration in the medium has not been reported. Likewise, the effect of $\mathrm{NaCl}$ concentration in the medium on the mRNA expression abundance of $\mathrm{N}$ removal-related enzyme genes has not been reported. However, the studies cited above help reveal the mechanism of salt tolerance during the growth and $\mathrm{N}$ removal by Halomonas.

This paper describes the stress effects of high osmotic pressure on the growth of Halomonas sp. B01 and its response mechanism. The effects of the $\mathrm{NaCl}$ concentration in the medium on the activity levels of growth-related enzymes (glucokinase (GK); dehydrogenase (DHA); and succinate dehydrogenase $(\mathrm{SDH})$ ) and $\mathrm{N}$ removal-related enzymes (ammonia monooxygenase (AMO) and nitrite reductase (NIR)) in Halomonas sp. B01 were characterized. Real-time quantitative PCR (RT-PCR) was used to investigate the effect of $\mathrm{NaCl}$ concentration in the medium on the mRNA expression abundance of AMO-encoding gene $(a m o A)$ in this strain. The $\mathrm{N}$ removal process of the strain under high salinity was also investigated. Thus, the growth and $\mathrm{N}$ removal of Halomonas sp. B01 under high salinity were characterized.

\section{Materials and methods}

\section{Materials}

Strain Halomonas sp. B01 was isolated, screened, and identified by the author's previous study (16S rRNA sequence GenBank No. KJ778559) (Wang et al. 2017), and the strain was deposited in the China Center for Type Culture Collection (CCTCC) under the accession number CCTCC AB 2014335.

Drugs and kits Ectoine standard was purchased from Biomol GmbH (Germany). TaKaRa MiniBEST Universal RNA Extraction Kit (TaKaRa Code: 9767), TaKaRa PrimeScript ${ }^{\mathrm{TM}}$ RT reagent Kit with gDNA Eraser (Perfect Real Time) (TaKaRa Code: RR047), and SYBR Premix Ex $T a q^{T M}$ II (TliRNaseH Plus) (TaKaRa Code: RR820) were purchased from Takara Biotechnology (Dalian) Co., Ltd. Malondialdehyde Determination Kit (BC0020), BCA Protein Concentration Assay Kit (PC0020), glucose-6phosphate dehydrogenase, and reduced coenzyme II (nicotinamide adenine dinucleotide phosphate) were purchased from Beijing Solarbio Science\&Technology Co., Ltd.

\section{Medium}

LB medium $\left(\mathrm{g} \mathrm{L}^{-1}\right)$ : peptone 10 , yeast extract powder $5, \mathrm{NaCl}$ 60. The medium was autoclaved at $121^{\circ} \mathrm{C}$ for $20 \mathrm{~min}$.

Growth medium $\left(\mathrm{g} \mathrm{L}^{-1}\right)$ : glucose $40,\left(\mathrm{NH}_{4}\right)_{2} \mathrm{SO}_{4} 10$, yeast extract powder $0.5, \mathrm{~K}_{2} \mathrm{HPO}_{4} \cdot 3 \mathrm{H}_{2} \mathrm{O} 9, \mathrm{KH}_{2} \mathrm{PO}_{4} 3, \mathrm{MgSO}_{4}$. $7 \mathrm{H}_{2} \mathrm{O} 0.4, \mathrm{MnSO}_{4} \cdot \mathrm{H}_{2} \mathrm{O} 0.01, \mathrm{NaCl}(30,60,90,120), \mathrm{pH}$ 7.2. The medium was autoclaved at $121^{\circ} \mathrm{C}$ for $20 \mathrm{~min}$.

$\mathrm{N}$ removal medium $\left(\mathrm{g} \mathrm{L}^{-1}\right)$ : $\left(\mathrm{NH}_{4}\right)_{2} \mathrm{SO}_{4} 10$, sodium succinate $35.8, \mathrm{~K}_{2} \mathrm{HPO}_{4} \cdot 3 \mathrm{H}_{2} \mathrm{O} 9, \mathrm{KH}_{2} \mathrm{PO}_{4} 3, \mathrm{MgSO}_{4} \cdot 7 \mathrm{H}_{2} \mathrm{O} 0.1$, $\mathrm{NaCl}(30,60,90,120$ respectively), $\mathrm{pH}$ 8. The $\mathrm{N}$ removal medium was autoclaved at $121^{\circ} \mathrm{C}$ for $20 \mathrm{~min}$. Trace mineral solution (EDTA-2Na 63.7, $\mathrm{ZnSO}_{4} 2.2, \mathrm{CaCl}_{2} 5.5, \mathrm{MnCl}_{2}$. $4 \mathrm{H}_{2} \mathrm{O} 5.1, \mathrm{FeSO}_{4} \cdot 7 \mathrm{H}_{2} \mathrm{O} 5, \mathrm{Na}_{2} \mathrm{MO}_{4} \cdot 2 \mathrm{H}_{2} \mathrm{O} 1.1, \mathrm{CuSO}_{4}$. $5 \mathrm{H}_{2} \mathrm{O} 1.6, \mathrm{CoCl}_{2} \cdot 6 \mathrm{H}_{2} \mathrm{O} 1.6, \mathrm{~g} \mathrm{~L}^{-1}$ ) was at $2 \mathrm{~mL}$. The trace mineral solution was sterilized by filtration $(0.22 \mu \mathrm{m}$ pore size, Millipore Express, USA).

\section{SND method}

The N removal by SND in this paper was simultaneous heterotrophic nitrification and aerobic denitrification, so the $\mathrm{N}$ removal conditions were set to heterotrophic ( $\mathrm{N}$ removal medium containing organic carbon compound sodium succinate) and aerobic (using rotary shaker ventilation to provide oxygen in the $\mathrm{N}$ removal process). The strains were cultivated in $5 \mathrm{~mL}$ of LB medium at $30^{\circ} \mathrm{C}$ in a rotary shaker at $120 \mathrm{rpm}$ for $24 \mathrm{~h}$. Then, $1 \%$ of the cultures were inoculated in shake flasks (300 $\mathrm{mL}$ ) containing $30 \mathrm{~mL}$ of $\mathrm{N}$ removal medium, and the SND was performed at $30{ }^{\circ} \mathrm{C}$ in a rotary shaker at $90 \mathrm{rpm}$. 


\section{Methods for assaying strain growth and metabolic stress in cultures with different salt concentrations and ability of strain to respond to the stress}

The stress of growth and metabolism of the strain in cultures with different salt concentrations was investigated: The inhibition of cell growth by different salt concentrations was evaluated by measuring the amount of cell growth; the lipid peroxidation under high salinity was evaluated by measuring the concentration of malondialdehyde (MDA). The ability of strains to respond to stress under high salinity was investigated: The salt-tolerant growth ability of the strain was evaluated by measuring intracellular ectoine concentration; the repair ability of the strain to lipid peroxidation was evaluated by measuring the SOD activity. The samples to be determined were the cultures which incubated for $36 \mathrm{~h}$ in the growth medium with different $\mathrm{NaCl}$ concentrations.

The cell growth was assayed as follows: Cell dry weight (CDW) with different $\mathrm{OD}_{600}$ was determined. The relationship between $\mathrm{CDW}$ and $\mathrm{OD}_{600}$ was calculated. $\mathrm{CDW}$ was calculated by determining the $\mathrm{OD}_{600}$ in experiment. Cell growth was defined as CDW per liter culture broth $\left(\mathrm{g} \mathrm{L}^{-1}\right)$.

The ectoine concentration was assayed as follows: The sample for determining ectoine was prepared by ethanol extraction method (Zhang et al. 2009). Ectoine was determined by high-performance liquid chromatography (HPLC) method (Zhang et al. 2009). An HPLC was equipped with a TSK-GEL reversed-phase column (TOSOH Corporation, Japan). A UV detector wavelength of $210 \mathrm{~nm}$ was used.

The MDA concentration was assayed as follows: MDA was determined using Malondialdehyde Determination Kit (BC0020, Solarbio, Beijing, China).

The SOD activity was assayed as follows: Pyrogallol rapidly autoxidizes under alkaline conditions. SOD can inhibit the autoxidation of pyrogallol (Wu et al. 2011). One unit of SOD activity (U) is the amount of SOD that catalyze the inhibition of pyrogallol autoxidation at a rate of $50 \%$ per min at the reaction substrate of pyrogallol $\left(21 \mathrm{mmol} \mathrm{L}^{-1}\right)$, $\mathrm{pH} 8.2$ and $30^{\circ} \mathrm{C}$ under the specified reaction conditions. The sample is to be determined using the preparation liquid of cytoplasmic enzyme (including the periplasmic enzyme). Methods for preparing enzyme liquid to be determined and assayed protein concentration see "Methods for assaying growth-related and $\mathrm{N}$ removal-related enzyme activity."

\section{Methods for assaying growth-related and $\mathbf{N}$ removal-related enzyme activity}

The salt tolerance during the growth and $\mathrm{N}$ removal of the strain was evaluated by measuring the activities of growthrelated and $\mathrm{N}$ removal-related enzymes in cultures with different salt concentrations. Growth-related enzymes selected GK, DHA, and DHA as markers for growth-related enzyme activity (Szeto et al. 2007; Zhang et al. 2008; Wolińska and Stępniewska 2012). The N removal-related enzymes selected AMO and NIR, which are key enzymes in the heterotrophic nitrification process and aerobic denitrification process, respectively (Ensign et al. 1993; Tavares et al. 2006).

The enzyme solution to be assayed was prepared as follows: SOD and growth-related enzymes (GK, DHA, and DHA) were from cultures which incubated for $36 \mathrm{~h}$ in growth medium with different $\mathrm{NaCl}$ concentrations. $\mathrm{N}$ removal-related enzymes (AMO and NIR) were from cultures which incubated for $36 \mathrm{~h}$ in $\mathrm{N}$ removal medium with different $\mathrm{NaCl}$ concentrations. A crude extract of each enzyme prepared for this study was used for enzyme activity assays. The following enzymes were studied: SOD and GK are cytoplasmic enzymes (Dols et al. 1997; Valdivia et al. 2009), NIR is a cell periplasmic enzyme (Blackmore et al. 1986), and SDH and AMO are cell membrane-bound enzymes (Hyman and Arp 1992; Miyadera et al. 2003). The cytoplasmic enzyme (including the periplasmic enzyme) was prepared in $20 \mathrm{~mL}$ of the cell culture medium, which was also used to determine enzyme activity, which was centrifuged at $14000 \times g$ for $15 \mathrm{~min}$ at $4{ }^{\circ} \mathrm{C}$, and the supernatant was discarded. Then, $100 \mathrm{mM} \mathrm{pH} 7.2$ phosphate buffer was added to the centrifuged pellet to resuspend it. A freeze-thaw cycle (at $-20{ }^{\circ} \mathrm{C} \geq 2 \mathrm{~h}$ and at $30{ }^{\circ} \mathrm{C}$ for $30 \mathrm{~min}$.) was repeated 4 times. Ultrasound was used to disrupt cells in an ice bath (sonicated at $400 \mathrm{~W}$ for $3 \mathrm{~s}$ and stopped for $3 \mathrm{~s}$ ) continuously through 30 cycles to obtain a solution of disrupted cells. The disrupted-cell solution was centrifuged at $14000 \times g$ for $15 \mathrm{~min}$ at $4{ }^{\circ} \mathrm{C}$, the supernatant was collected, and the sample was used for cytoplasmic and periplasmic enzyme assays. The membranebound enzyme was prepared as follows: The disrupted-cell centrifuge pellet, as described above, was resuspended in $100 \mathrm{mM}$ phosphate buffer ( $\mathrm{pH}$ 7.2) containing $1.0 \%$ dodecyl- $\beta$-Dmaltoside, incubated for $1 \mathrm{~h}$ at $4{ }^{\circ} \mathrm{C}$ in the dark, and centrifuged at $14000 \times g$ for $15 \mathrm{~min}$ at $4{ }^{\circ} \mathrm{C}$. Then, the supernatant was collected, and the sample was used for the cell membrane-bound enzyme assay (Zhang et al. 2015). The total protein concentration of the enzyme solution to be determined was assayed as follows: Protein was determined using the BCA Protein Concentration Assay Kit (PC0020, Solarbio, Beijing, China). The amount of the enzyme solution to be determined was based on the total protein (mg).

The GK activity was assayed as follows: GK converts glucose into glucose-6-phosphate, and then, glucose-6-phosphate dehydrogenase (G-6-PDH) converts glucose-6-phosphate into glucose acid 6-phosphate and reductive coenzyme II (Algar and Scopes 1985; Miyata and Yonehara 1999). One unit of GK activity (U) is the amount of GK that produces $1 \mu \mathrm{mol}$ of reductive coenzyme II per min at the reaction substrate of glucose $\left(1 \mathrm{~mol} \mathrm{~L}^{-1}\right), \mathrm{pH} 7.8$ and $30^{\circ} \mathrm{C}$, under the specified reaction conditions. The sample is to be determined using the preparation liquid of cytoplasmic enzyme (including the periplasmic enzyme). 
The DHA activity was assayed as follows: The activity of DHA was measured using triphenyl tetrazolium chloride (TTC) salt as a hydrogen acceptor. TTC is a colorless salt, but in the presence of DHA, it is reduced to triphenylformazan (TPF), a red compound insoluble in water. TPF is extracted with $\mathrm{CHCl}_{3}$ and measured at $485 \mathrm{~nm}$ (Jafari et al. 2015). One unit of DHA activity (U) is the amount of DHA that produces $1 \mu \mathrm{mol}$ of TPF per min at the reaction substrate of TTCglucose solution $\left(0.7 \mathrm{mmol} \mathrm{L}^{-1}\right), \mathrm{pH} 8.4$ and $30{ }^{\circ} \mathrm{C}$, under the specified reaction conditions. The samples to be determined were the cell obtained by centrifugation of the cultures which incubated for $36 \mathrm{~h}$ in the growth medium with different $\mathrm{NaCl}$ concentrations. The amount of the cell to be determined was based on the CDW (g).

The SDH activity was assayed as follows: SDH can catalyze the dehydrogenation of succinic acid to create fumaric acid while reducing methylene blue to methylene white (colorless) (Moller-Zinkhan and Thauer 1988). One unit of $\mathrm{SDH}$ activity (U) is the amount of SDH that reduces the $A_{665}$ value of the reaction by 0.01 per min at the reaction substrate of sodium succinate $\left(0.1 \mathrm{~mol} \mathrm{~L}^{-1}\right), \mathrm{pH} 7.3$ and 30 ${ }^{\circ} \mathrm{C}$, under the specified reaction conditions. The sample is to be determined using the preparation liquid of cell membranebound enzyme.

The AMO activity was assayed as follows: AMO oxidization of $\mathrm{NH}_{4}{ }^{+}$to generate hydroxylamine (Ensign et al. 1993). One unit of AMO activity (U) is the amount of AMO that oxidizes $1 \mu \mathrm{mol} \mathrm{NH}_{4}{ }^{+}$per min at the reaction substrate of $\left(\mathrm{NH}_{4}\right)_{2} \mathrm{SO}_{4}\left(0.2 \mathrm{mmol} \mathrm{L}{ }^{-1}\right), \mathrm{pH} 7.2$ and $30{ }^{\circ} \mathrm{C}$, under the specified reaction conditions. The sample is to be determined using the preparation liquid of cell membranebound enzyme.

The NIR activity was assayed as follows: One unit of NIR activity $(\mathrm{U})$ is the amount of NIR that reduces $1 \mu \mathrm{mol} \mathrm{NO}_{2}{ }^{-}$ per min at the reaction substrate of $\mathrm{KNO}_{2}\left(0.5 \mathrm{mmol} \mathrm{L}^{-1}\right), \mathrm{pH}$ 7.2 and $30{ }^{\circ} \mathrm{C}$, under the specified reaction conditions (Martínez-Espinosa 2001). The sample is to be determined using the preparation liquid of cytoplasmic enzyme (including the periplasmic enzyme).

\section{Method of RT-PCR}

RT-PCR was performed by SYBR Green I fluorescent dye method (Marino et al. 2003). The 16S rDNA sequence primers of Halomonas sp. B01 were 16S rDNA universal primers for bacterial, which were $\mathrm{F}_{1}$ - ACATCCTG CGAACTTGTGAGAG and $\mathrm{R}_{1}$ - CCGCTGGCAAATAA GGACA. The amoA primers of Halomonas sp. B01 were $\mathrm{F}_{2}$ - GCTGGTATCGGCAAAAGGAA and $\mathrm{R}_{2}$ CCCAGCACCAATCCCATAAC. The nucleotide sequence of Halomonas sp. B01 amoA had been registered on GenBank (KT809509). The total RNA of samples were extracted using TaKaRa MiniBEST Universal RNA Extraction
Kit (TaKaRa Code: 9767). RT-PCR was performed using TaKaRa PrimeScript ${ }^{\mathrm{TM}}$ RT reagent Kit with gDNA Eraser (Perfect Real Time) (TaKaRa Code: RR047) and SYBR Premix Ex Taq ${ }^{\mathrm{TM}}$ II (TliRNaseHPlus)(TaKaRa Code: RR820) in apparatus of TaKaRa PCR Thermal Cycler Dice $^{\text {TM }}$ (TaKaRa Code: TP600) and TaKaRa PCR Thermal Cycler Dice $^{\mathrm{TM}}$ Real-Time System (TaKaRa Code: TP800). RT-PCR results were processed using Delta-delta $\mathrm{Ct}$ method. The mRNA expression abundance of $a m o A$ was expressed by $2^{-\Delta \Delta \mathrm{Ct}}$.

\section{Methods for determining inorganic $\mathbf{N}$ concentration}

The inorganic $\mathrm{N}$ herein include $\mathrm{NH}_{4}{ }^{+}-\mathrm{N}, \mathrm{NO}_{2}-\mathrm{N}$, and $\mathrm{NO}_{3}{ }^{-}$ $\mathrm{N}$, and the $\mathrm{N}$ removal rate of the strain was evaluated by measuring the concentration of inorganic $\mathrm{N}$. $\mathrm{NH}_{4}{ }^{+}-\mathrm{N}$ was determined by Nessler's reagent method (APHA 1999). $\mathrm{NO}_{2}{ }^{-}-\mathrm{N}$ was determined by diazotization-coupling reaction method (APHA 1999). $\mathrm{NO}_{3}{ }^{-}-\mathrm{N}$ was determined by zinc-cadmium reduction method (Sun et al. 2013).

Three parallel samples were set up for all the above experiments. The average of the three measurements with standard deviation values is presented in the results section.

\section{Results and discussion}

\section{Response of Halomonas sp. B01 to stress from high concentrations of $\mathrm{NaCl}$}

The concentration of compatible solute ectoine synthesized by Halomonas sp. B01 was investigated under $\mathrm{NaCl}$ stress. This study assessed cell growth and the intracellular ectoine concentration in Halomonas sp. B01 after being cultured for $36 \mathrm{~h}$ in growth medium containing 30,60, 90, and $120 \mathrm{~g} \mathrm{~L}^{-1} \mathrm{NaCl}$, respectively; the results are shown in Fig. 1b. At a NaCl concentration of $120 \mathrm{~g} \mathrm{~L}^{-1}$, the growth still reached $7.0 \mathrm{~g} \mathrm{~L}^{-1}$, and the intracellular ectoine concentration was $921.2 \mathrm{mg} \mathrm{L}^{-1}$. The intracellular ectoine concentration in Halomonas sp. B01 increased with increased $\mathrm{NaCl}$ concentration in the growth medium. Halomonas sp. B01 responded to high salt stress by synthesizing a compatible solute protection mechanism.

The effect of $\mathrm{NaCl}$ stress on lipid peroxidation in Halomonas sp. B01 cells was also investigated. The intracellular MDA concentration and SOD activity in Halomonas sp. B01 after being cultured for $36 \mathrm{~h}$ in growth medium containing 30, 60, 90, and $120 \mathrm{~g} \mathrm{~L}^{-1} \mathrm{NaCl}$ are shown in Fig. 1c. With the increase in $\mathrm{NaCl}$ concentration, synchronous changes in the activity of SOD and in the cytoplasmic concentration of MDA were observed. When the concentration of $\mathrm{NaCl}$ reached $120 \mathrm{~g} \mathrm{~L}^{-1}$, the intracellular MDA concentration increased significantly $\left(576.1 \mu \mathrm{g} \mathrm{mg}^{-1}\right)$, indicating that significant lipid peroxidation transpired in Halomonas sp. B01 under 

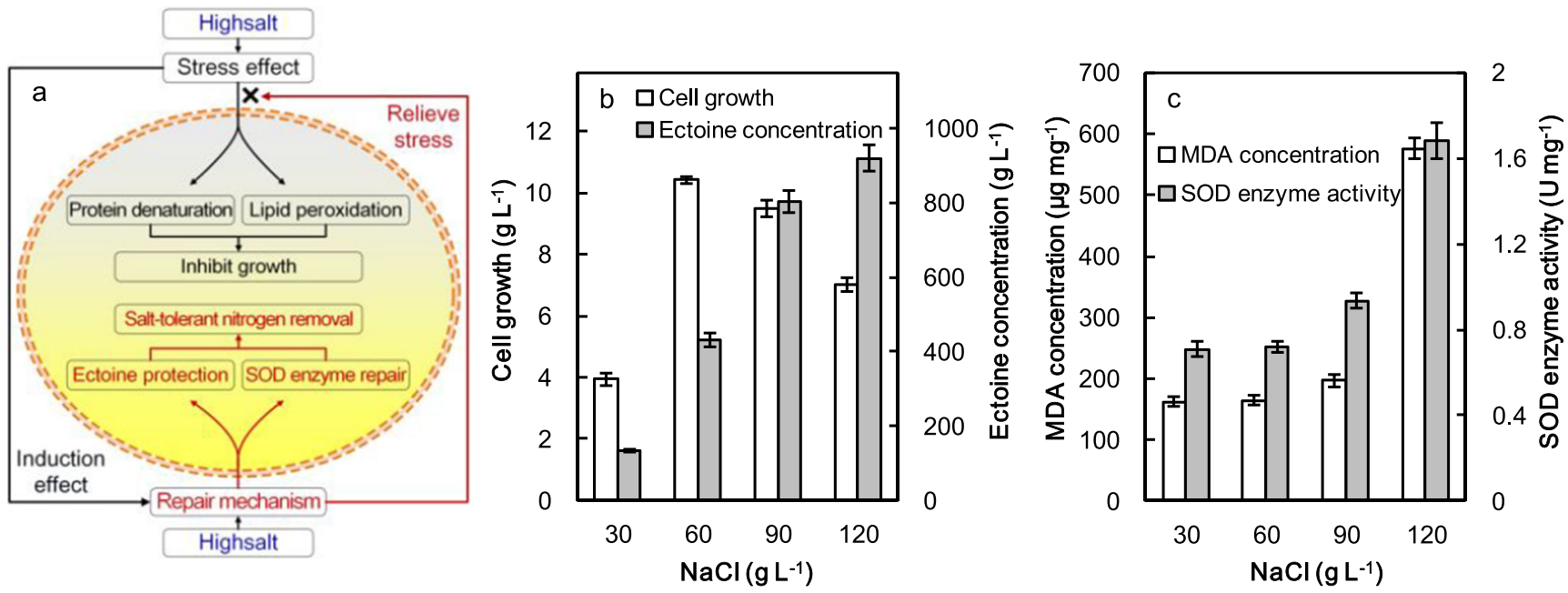

Fig. 1 a Response of Halomonas sp. B01 to stress from high concentrations of $\mathrm{NaCl}$. b Cell growth and induced ectoine concentration in cultures at different $\mathrm{NaCl}$ concentrations. c MDA

concentration and SOD activity in cells cultured with different $\mathrm{NaCl}$ concentrations. Cells were incubated in growth medium at $30{ }^{\circ} \mathrm{C}$ while shaking at $120 \mathrm{rpm}$ for $36 \mathrm{~h}$

this high osmotic pressure. In addition, the SOD activity was also significantly increased $\left(1.7 \mathrm{U} \mathrm{mg}^{-1}\right)$, indicating that while Halomonas sp. B01 was undergoing lipid peroxidation, the SOD repair mechanism was initiated, allowing the cells to tolerate the salt and be able to grow and metabolize.

The above results indicated that Halomonas sp. B01 responds to high osmotic pressure stress in two ways. One was the protective mechanism of synthetic compatible solutes; the other was the repair mechanism of SOD for lipid peroxidation. The amount of ectoine synthesis and the increase of $\mathrm{NaCl}$ concentration increased substantially simultaneously. The concentration of MDA and SOD activity increased significantly when the $\mathrm{NaCl}$ concentration reached $120 \mathrm{~g} \mathrm{~L}^{-1}$, indicating that lipid peroxidation was severe at this time and the corresponding SOD repair effect was also significantly increased.

Based on existing research (Komanapalli and Lau 1996; Uygur and Karg1 2004; Valdivia et al. 2009; Vyrides and Stuckey 2009; Pastor et al. 2010; Wang et al. 2017) and studies in this paper, the response mechanism of Halomonas sp. B01 to high osmotic pressure stress could be described as follows (Fig. 1a): High salt-induced osmotic pressure had at least two stress effects on Halomonas sp. B01, the first being the denaturation and reduction biological macromolecule activities (such as proteins) and the second being lipid peroxidation. These two types of stress could lead to a decrease of cell growth and growth rate and a decrease of metabolic activity. The response of Halomonas sp. B01 to these two osmotic pressure stress effects was the synthetic compatible solute protection mechanism and the SOD repair mechanism. The synthesis of compatible solute ectoine increased in line with cell growth, while the large amount of MDA and the significant increase of SOD activity both occurred at $120 \mathrm{~g}$ $\mathrm{L}^{-1} \mathrm{NaCl}$ in the medium, indicating that the synthesis of compatible solute was the first protective mechanism initiated by Halomonas sp. B01, and the SOD repair mechanism was the protective mechanism activated by this strain in response to increasingly extreme conditions. The two response mechanisms to high osmotic pressure stress in Halomonas sp. B01 enabled it to show significant salt-tolerant growth characteristics for a wide range of $\mathrm{NaCl}$ concentrations $\left(30-120 \mathrm{~g} \mathrm{~L}^{-1}\right)$, such that, at $120 \mathrm{~g} \mathrm{~L}^{-1}$, the cell growth of the strain was $7.0 \mathrm{~g}$ $\mathrm{L}^{-1}$, and it reached $67.3 \%$ of the greatest level of growth (10.4 $\mathrm{g} \mathrm{L}^{-1}$ ) in $60 \mathrm{~g} \mathrm{~L}^{-1} \mathrm{NaCl}$ in the medium.

\section{Effects of salt concentration in the medium on growth-related enzyme activity in Halomonas sp. B01}

The three core pathways of cell growth and metabolism include Embden-Meyerhof-Parnas pathway (EMP), hexose monophosphate pathway (HMP), and tricarboxylic acid cycle (TCA). GK (EC 2.7.1.2) is a limiting enzyme for the use of glucose in the EMP pathway, and its catalytic reaction is Dglucose + ATP $\rightarrow$ D-glucose 6-phosphate + ADP (Zhang et al. 2008). DHA is involved in redox reactions in cells and passes electrons through the respiratory chain to hydrogen receptors under certain conditions. DHA activity, especially which in the three core metabolic pathways, is considered to be a good indicator of microbial oxidation activity (Wolińska and Stępniewska 2012). SDH (EC 1.3.5.1) in the TCA cycle has been used as an indicator to evaluate the degree of tricarboxylic acid cycling, and its catalytic reaction is succinate + a quinone $\rightarrow$ fumarate + a quinol (Szeto et al. 2007). In this study, the activities of Halomonas sp. B01 GK, DHA, and SDH were used as markers of growth and metabolic related enzyme activity. The activities of the three enzymes in Halomonas sp. B01 were investigated in medium with 
concentrations in the range of $30-120 \mathrm{~g} \mathrm{~L}^{-1} \mathrm{NaCl}$. The results are shown in Fig. 2. The GK and SDH activity levels were the highest in $60 \mathrm{~g} \mathrm{~L}^{-1} \mathrm{NaCl}$ medium, at $6.0 \mathrm{U} \mathrm{mg}^{-1}$ and $4.3 \mathrm{U}$ $\mathrm{mg}^{-1}$, respectively. The DHA activity level was higher in 30 and $60 \mathrm{~g} \mathrm{~L}^{-1} \mathrm{NaCl}$ medium $\left(8.1 \mathrm{U} \mathrm{g}^{-1}\right.$ and $7.7 \mathrm{U} \mathrm{g}^{-1}$, respectively) than in the other salt concentrations assayed. Thus, the three enzymes, which are related to the growth and metabolism of Halomonas sp. B01, showed significant high salt adaptability.

\section{Effects of salt concentration in the medium on $\mathbf{N}$ removal-related enzyme activity levels in Halomonas sp. B01}

The process of microbial $\mathrm{N}$ removal is generally $\mathrm{NH}_{4}{ }^{+} \rightarrow$ $\mathrm{NO}_{2}{ }^{-} \rightarrow \mathrm{NO}_{3}{ }^{-} \rightarrow \mathrm{NO}_{2}{ }^{-} \rightarrow \mathrm{NO} \rightarrow \mathrm{N}_{2} \mathrm{O} \rightarrow \mathrm{N}_{2}$, in which $\mathrm{NH}_{4}{ }^{+} \rightarrow \mathrm{NO}_{2}{ }^{-}$is catalyzed by AMO and $\mathrm{NO}_{2}{ }^{-} \rightarrow \mathrm{NO}$ is catalyzed by NIR. These two enzymes belong to the nitrification and denitrification enzymes of the $\mathrm{N}$ removal process, respectively. AMO is the first key enzyme in the process of heterotrophic nitrification, and NIR is also one of the key enzymes in the process of aerobic denitrification (Ensign et al. 1993; Tavares et al. 2006). The salt tolerance of these two enzymes has an effect on the $\mathrm{N}$ removal efficiency of SND under high salinity. The effects of salt concentration in the culture medium on the $\mathrm{N}$ removal-related enzyme activity of Halomonas sp. B01 were investigated. Halomonas sp. B01 was cultured for $36 \mathrm{~h}$ in a growth medium containing 30,60 , 90 , and $120 \mathrm{~g} \mathrm{~L}^{-1} \mathrm{NaCl}$, respectively, and the enzyme solution was prepared according to the method described in "Methods for assaying growth-related and $\mathrm{N}$ removal-related enzyme activity" to determine the activity levels of AMO and NIR. The results are shown in Fig. 3. Figure 3 showed that the optimum salt concentration in the culture to activate AMO

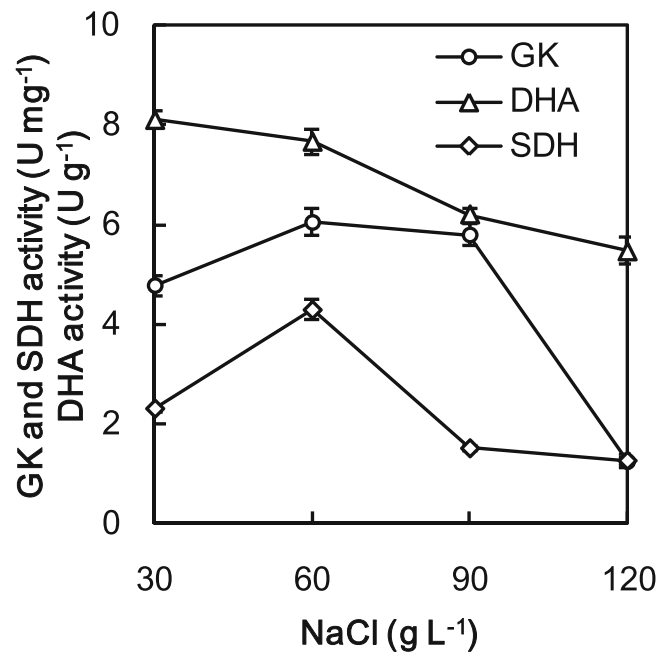

Fig. 2 Effects of salt concentration in the medium on growth-related enzyme activities in Halomonas sp. B01. The temperature of enzyme reaction system was $30^{\circ} \mathrm{C}$, and reaction time was $1 \mathrm{~h}$ and NIR was $60 \mathrm{~g} \mathrm{~L}^{-1} \mathrm{NaCl}$, and the two enzyme activity levels were $14.9 \mathrm{U} \mathrm{mg}^{-1}$ and $20.3 \mathrm{U} \mathrm{mg}^{-1}$, respectively. AMO had higher activity $\left(14.6 \mathrm{U} \mathrm{mg}^{-1}\right.$ and $14.9 \mathrm{U} \mathrm{mg}^{-1}$, respectively) in culture media with 30 and $60 \mathrm{~g} \mathrm{~L}^{-1} \mathrm{NaCl}$, while NIR had significantly higher activity in the culture medium with $60 \mathrm{~g} \mathrm{~L}^{-1} \mathrm{NaCl}$. At the extreme salt concentration condition $\left(120 \mathrm{~g} \mathrm{~L}^{-1} \mathrm{NaCl}\right)$, cells retained a certain level of enzyme activity.

The results of this study demonstrated for the first time that the salt tolerance of Halomonas strains on growth and $\mathrm{N}$ removal is not only due to the protective effect of compatible solute on intracellular macromolecules (Pastor et al. 2010), but also directly related on the salt tolerance (in vitro enzyme activity) of its growth-related and $\mathrm{N}$ removal-related enzymes.

\section{Effect of salt concentration in the medium on amo $A$ mRNA expression abundance in Halomonas sp. B01}

RT-PCR was used to investigate the effect of salt concentration in the medium on mRNA expression abundance of the AMO-encoding gene amoA in Halomonas sp. B01. Experimental samples were prepared by extracting total mRNA at values of $A_{260 / 280} \geq 2.0$. The amplification curves for the samples were S-type curves, and the melting point for a specific amplified primer was visualized as a single peak. The standard deviation of expression for parallel samples was less than or equal to $0.3 \%$.

The mRNA expression abundance of amoA in growth medium at different $\mathrm{NaCl}$ concentrations for $36 \mathrm{~h}$ is shown in Fig. 4. The mRNA abundance was highest (3.5) at $60 \mathrm{~g} \mathrm{~L}^{-1} \mathrm{NaCl}$ (within the concentration range of $30-120 \mathrm{~g} \mathrm{~L}^{-1} \mathrm{NaCl}$ ). The salt tolerance of the Halomonas strain on grow and $\mathrm{N}$ removal is also reflected in the gene expression level.

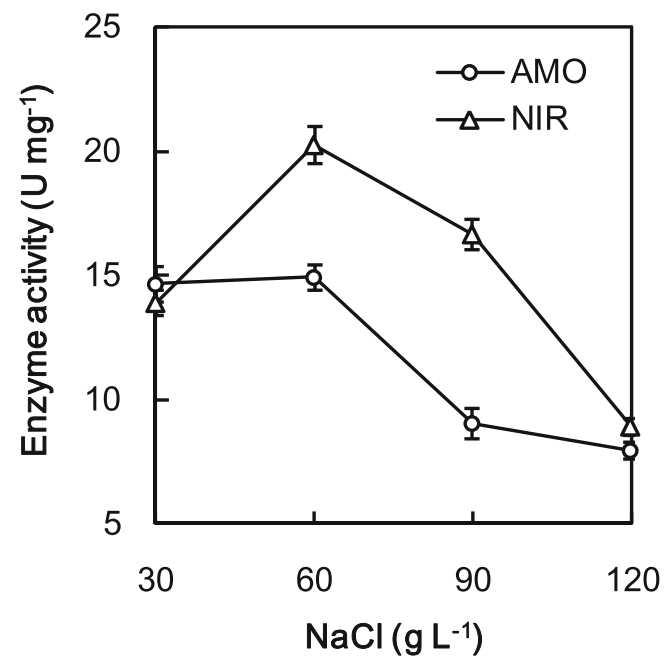

Fig. 3 Effects of salt concentration in the medium on the $\mathrm{N}$ removalrelated enzyme activity in Halomonas sp. B01. The temperature of enzyme reaction system was $30^{\circ} \mathrm{C}$, and reaction time was $1 \mathrm{~h}$ 


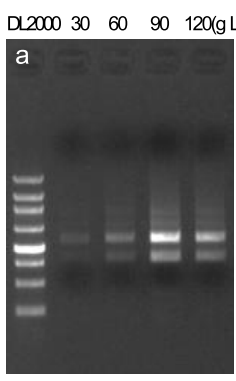

Electrophoresis of RNA

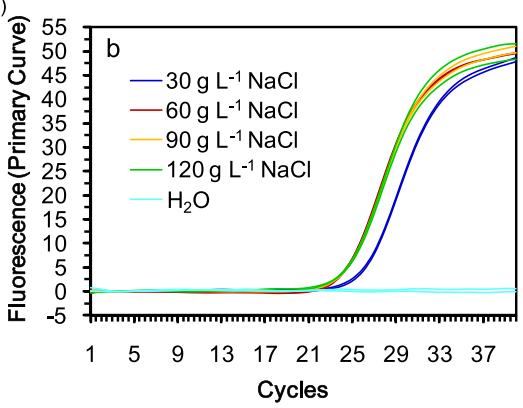

Fig. 4 Effect of salt concentration in the medium on amoA mRNA expression abundance in Halomonas sp. B01. a Agarose gel electrophoresis pattern of total RNA extracted from the strain samples cultured at different $\mathrm{NaCl}$ concentrations. b RT-PCR amplification curves of $a m o A$ from strain samples cultured at different $\mathrm{NaCl}$ concentrations. c

\section{SND process under different $\mathrm{NaCl}$ concentrations}

The $\mathrm{N}$ removal process of Halomonas sp. $\mathrm{B} 01$ at different $\mathrm{NaCl}$ concentrations was investigated. The results are shown in Fig. 5. In the concentration range of $30-120 \mathrm{~g} \mathrm{~L}^{-1} \mathrm{NaCl}$, the strain was able to remove $\mathrm{N}$ through $\mathrm{SND}$, and the $\mathrm{N}$ removal rate increased with time. At a $60 \mathrm{~g} \mathrm{~L}^{-1} \mathrm{NaCl}$ concentration, the $\mathrm{N}$ removal process had the highest $\mathrm{N}$ removal rate, which reached $98.8 \%$ in $96 \mathrm{~h}$. Under the extremely high salt level of $120 \mathrm{~g} \mathrm{~L}^{-1}$ $\mathrm{NaCl}$, the strain showed high $\mathrm{N}$ removal efficiency, and the $\mathrm{N}$ removal rate reached $89.8 \%$ at $96 \mathrm{~h}$. The $\mathrm{N}$ removal with SND by Halomonas sp. B01 had significant salt tolerance (the initial $\mathrm{NH}_{4}{ }^{+}-\mathrm{N}$ concentration was $2121 \mathrm{mg} \mathrm{L}^{-1}$ ).

By simulating saltwater intrusion, Yang studied the effects of saltwater intrusion on microorganisms in the rhizosphere soil of riparian zone of Chongming Island, Shanghai, China. The denitrification process of these microorganisms in rhizosphere soil was also studied. The results showed that the nitrite reductase activity of the rhizosphere soil microorganism

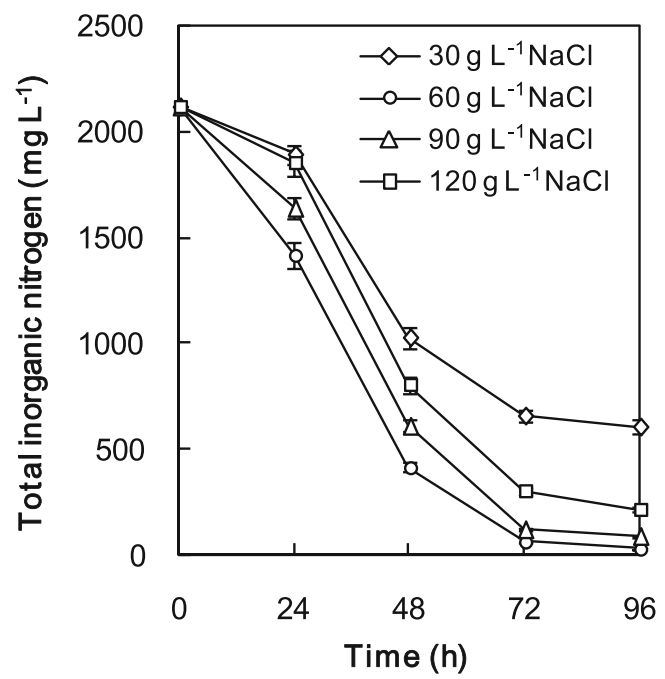

Fig. 5 The $\mathrm{N}$ removal process of Halomonas sp. B01 at different $\mathrm{NaCl}$ concentrations. Measurements were taken from cultures in $\mathrm{N}$ removal medium at $30{ }^{\circ} \mathrm{C}$ while shaking at $90 \mathrm{rpm}$ in a rotary shaker
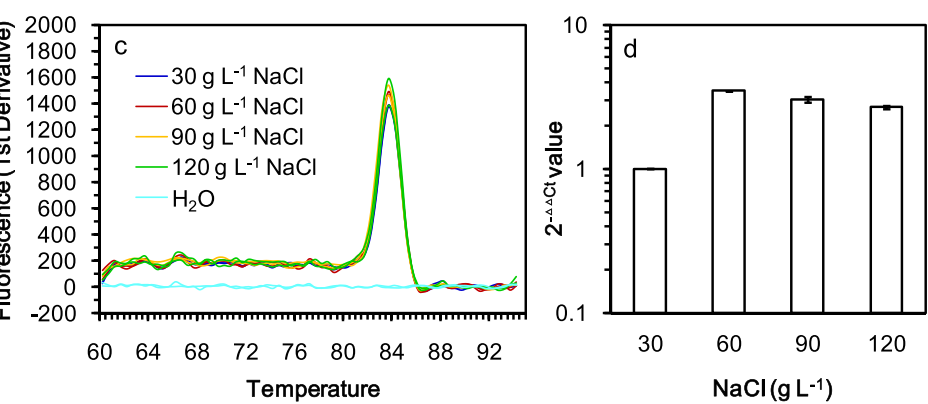

Dissolution curves of amoA amplification products from strain samples cultured at different $\mathrm{NaCl}$ concentrations. d mRNA expression abundance of amoA from strain samples cultured at different $\mathrm{NaCl}$ concentrations

decreased significantly (down 56.5\%) under the simulated saline water that contained $23.5 \mathrm{~g} \mathrm{~L}^{-1} \mathrm{NaCl}$ (Yang et al. 2012). This result indicated that, in general, nitrifying bacteria in the soil do not have salt tolerance (or low salt tolerance). Guo reported that under salt conditions, the nitrification rate of Halomonas was significantly higher than that of Bacillus. The former had a nitrification efficiency of $8.3 \mathrm{mg} \mathrm{NH}_{4}^{+}-\mathrm{N} \mathrm{L}^{-1}$ $\mathrm{h}^{-1}$, which was approximately three times greater than that of the latter (2.1 $\mathrm{mg} \mathrm{NH}_{4}{ }^{+}-\mathrm{N} \mathrm{L}^{-1} \mathrm{~h}^{-1}$ ) (Zhang et al. 2012; Guo et al. 2013). In the study cited, Halomonas showed high salt tolerance during $\mathrm{N}$ removal. Guo reported that the nitrification and denitrification efficiency of Halomonas campisalis ha3 under $4 \% \mathrm{NaCl}$ condition were $8.3 \mathrm{mg} \mathrm{NH}_{4}{ }^{+}-\mathrm{N} \mathrm{L}^{-1} \mathrm{~h}^{-1}$ and $87.5 \mathrm{mg} \mathrm{NO}_{3}{ }^{-}-\mathrm{N} \mathrm{L}^{-1} \mathrm{~h}^{-1}$, respectively (Guo et al. 2013). Sun reported that the optimum growth condition for a strain of Halomonas isolated and screened was 3\% salinity, and the $\mathrm{N}$ removal rate at seawater salt concentration was $98.3 \%$ (Sun et al. 2012). Qu reported that the total $\mathrm{N}$ removal rate of a Halomonas strain isolated and screened at $30 \mathrm{~g} \mathrm{~L}^{-1}$ salt concentration was $81.5 \%$ (Qu et al. 2011). Halomonas sp. B01 reported in this study had an optimum $\mathrm{NaCl}$ concentration of $60 \mathrm{~g} \mathrm{~L}^{-1}$ for growth and SND $\mathrm{N}$ removal. Under this condition, the $\mathrm{N}$ removal rate reached $98.8 \%$. This strain was the highest level reported in the genus Halomonas in terms of salt tolerance and $\mathrm{N}$ removal efficiency.

\section{Conclusion}

This study revealed that Halomonas sp. B01 possessed two sets of mechanisms for responding to high osmotic stress during the sequential increase of $\mathrm{NaCl}$ concentration in the culture environment. One is the protective mechanism of synthetic compatible solutes; the other is the repair mechanism of SOD for lipid peroxidation. The activity levels of growthand metabolism-related and $\mathrm{N}$ removal-related enzymes in Halomonas sp. $\mathrm{B} 01$ were affected by $\mathrm{NaCl}$ concentration in the medium. The activity levels of GK and SDH showed 
maximum values ( $6.0 \mathrm{U} \mathrm{mg}^{-1}$ and $4.3 \mathrm{U} \mathrm{mg}^{-1}$, respectively) under conditions of $60 \mathrm{~g} \mathrm{~L}^{-1} \mathrm{NaCl}$ in culture. The activity of DHA was higher $\left(8.1 \mathrm{U} \mathrm{g}^{-1}\right.$ and $\left.7.7 \mathrm{U} \mathrm{g}^{-1}\right)$ in the culture with 30 and $60 \mathrm{~g} \mathrm{~L}^{-1} \mathrm{NaCl}$, respectively. The optimum $\mathrm{NaCl}$ concentration in culture for AMO and NIR activity was $60 \mathrm{~g} \mathrm{~L}^{-1}$ $\mathrm{NaCl}$, and the enzyme activity was $14.9 \mathrm{U} \mathrm{mg}^{-1}$ and $20.3 \mathrm{U}$ $\mathrm{mg}^{-1}$, respectively. The mRNA expression abundance of amoA in Halomonas sp. B01 was highest at $60 \mathrm{~g} \mathrm{~L}^{-1} \mathrm{NaCl}$ in the range of $30-120 \mathrm{~g} \mathrm{~L}^{-1} \mathrm{NaCl}$ in the medium. At $2121 \mathrm{mg}$ $\mathrm{L}^{-1}$ initial $\mathrm{NH}_{4}{ }^{+}-\mathrm{N}$ and $60 \mathrm{~g} \mathrm{~L}^{-1} \mathrm{NaCl}$ in the medium, the highest $\mathrm{N}$ removal rate was obtained during the whole $\mathrm{N}$ removal process, and the $\mathrm{N}$ removal rate reached $98.8 \%$ in $96 \mathrm{~h}$. Until now, the effects of different salt concentrations on the growth-related and $\mathrm{N}$ removal-related enzymes in Halomonas and the effect of salt concentration in the medium on mRNA expression abundance of $\mathrm{N}$ removal-related enzymes encoding genes have not been reported. In this study, the growth and $\mathrm{N}$ removal of Halomonas sp. B01 under high salinity were characterized, which is of great significance for the microbial treatment of high-salinity nitrogenous wastewater.

Funding information This research was funded by the Fundamental Research Funds for the Central Universities and Collaborative Innovation Center for Vessel Pollution Monitoring and Control Seed Fund Project, Dalian Maritime University (20110216001).

\section{Compliance with ethical standards}

Conflict of interest The authors declare that they have no conflict of interest.

Research involving human participants and/or animals This article does not contain any studies with human participants or animals performed by any of the authors.

Informed consent N/A. This article does not involve human participants.

Open Access This article is distributed under the terms of the Creative Commons Attribution 4.0 International License (http:// creativecommons.org/licenses/by/4.0/), which permits unrestricted use, distribution, and reproduction in any medium, provided you give appropriate credit to the original author(s) and the source, provide a link to the Creative Commons license, and indicate if changes were made.

\section{References}

Algar EM, Scopes RK (1985) Studies on cell-free metabolism: ethanol production by extracts of Zymomonas mobilis. J Biotechnol 2:275287. https://doi.org/10.1016/0168-1656(85)90030-6

APHA (1999) Standard methods for the examination of water and wastewater 20th edn. American Public Health Association, Washington, DC

Berendes F, Gottschalk G, Heine-Dobbernack E, Moore ERB, Tindall BJ (1996) Halomonas desiderata sp. nov., a new alkaliphilic, halotolerant and denitrifying bacterium isolated from a municipal sewage works. Syst Appl Microbiol 19:158-167. https://doi.org/ 10.1016/S0723-2020(96)80041-5

Blackmore R, Roberton AM, Brittain T (1986) The purification and some equilibrium properties of the nitrite reductase of the bacterium Wolinella succinogenes. Biochem J 233:547-552. https://doi.org/ 10.1042/bj2330547

de la Haba RR, Arahal DR, Sanchez-Porro C, Ventosa A (2014) The prokaryotes: Gammaproteobacteria: 17 the family Halomonadaceae, Springer, Heidelberg https://doi.org/10.1007/ 978-3-642-38922-1 235

Dols M, Chraibi W, Remaud-Simeon M, Lindley ND, Monsan PF (1997) Growth and energetics of Leuconostoc mesenteroides NRRL B1299 during metabolism of various sugars and their consequences for dextransucrase production. Appl Environ Microbiol 63:2159 2165

Ensign SA, Hyman MR, ARP DJ (1993) In vitro activation of ammonia monooxygenase from Nitrosomonas europaea by copper. J Bacteriol 175:1971-1980. https://doi.org/10.1128/jb.175.7.19711980.1993

Guo Y, Zhou XM, Li YG, Li K, Wang CX, Liu JF, Yan DJ, Liu YL, Yang DH, Xing JM (2013) Heterotrophic nitrification and aerobic denitrification by a novel Halomonas campisalis. Biotechnol Lett 35: 2045-2049. https://doi.org/10.1007/s10529-013-1294-3

Hyman MR, Arp DJ (1992) ${ }^{14} \mathrm{C}_{2} \mathrm{H}_{2}$-and ${ }^{14} \mathrm{CO}_{2}$-1 abeling studies of the de Novo synthesis of polypeptides by Nitrosomonus europaea during recovery from acetylene and light inactivation of ammonia monooxygenase. J Biol Chem 267:1534-1545

Jafari SJ, Moussavi G, Yaghmaeian K (2015) High-rate biological denitrification in the cyclic rotating-bed biological reactor: effect of $\mathrm{COD} / \mathrm{NO}_{3}{ }^{-}$, nitrate concentration and salinity and the phylogenetic analysis of denitrifiers. Bioresour Technol 197:482-488. https://doi. org/10.1016/j.biortech.2015.08.047

Komanapalli IR, Lau BHS (1996) Ozone-induced damage of Escherichia coli K-12. Appl Microbiol Biotechnol 46:610-614. https://doi.org/ $10.1007 / \mathrm{s} 002530050869$

Marino JH, Cook P, Miller KS (2003) Accurate and statistically verified quantification of relative mRNA abundances using SYBR Green I and real-time RT-PCR. J Immunol Methods 283:291-306. https:// doi.org/10.1016/S0022-1759(03)00103-0

Martínez-Espinosa RM (2001) Purification and characterisation of a possible assimilatory nitrite reductase from the halophile archaeon Haloferax mediterranei. FEMS Microbiol Lett 196:113-118. https://doi.org/10.1016/S0378-1097(01)00044-1

Miyadera H, Hiraishi A, Miyoshi H, Sakamoto K, Mineki R, Murayama K, Nagashima KVP, Matsuura K, Kojima S, Kita K (2003) Complex II from phototrophic purple bacterium Rhodoferax fermentans displays rhodoquinol-fumarate reductase activity. Eur J Biochem 270: 1863-1874. https://doi.org/10.1046/j.1432-1033.2003.03553.x

Miyata R, Yonehara T (1999) Breeding of high-pyruvate-producing Torulopsis glabrata with acquired reduced pyruvate decarboxylase. J Biosci Bioeng 88:173-177. https://doi.org/10.1016/S13891723(99)80197-2

Moller-Zinkhan D, Thauer RK (1988) Membrane-bound NADPH dehydrogenase- and ferredoxin: NADP oxidoreductase activity involved in electron transport during acetate oxidation to $\mathrm{CO}_{2}$ in Desulfobacter postgatei. Arch Microbiol 150:145-154. https://doi. org/10.1007/BF00425154

Mormile MR, Romine MF, Garcia MT, Ventosa A, Bailey TJ, Peyton BM (1999) Halomonas campisalis sp. nov., a denitrifying, moderately haloalkaliphilic bacterium. Syst Appl Microbiol 22:551-558. https://doi.org/10.1016/S0723-2020(99)80008-3

Pastor JM, Salvador M, Argandoña M, Bernal V, Reina-Bueno M, Csonka LN, Iborra JL, Vargas C, Nieto JJ, Cánovas M (2010) Ectoines in cell stress protection: uses and biotechnological production. Biotechnol Adv 28:782-801. https://doi.org/10.1016/j. biotechadv.2010.06.005 
Qu Y, Zhang PY, Yang RX, Guo SS, Yu DS (2011) Characteristics of removal nitrogen and halotolerancy of halotolerant heterotrophic nitrifying strain qy18 and moderately halophilic heterotrophic nitrifying strain gs2. Mar Environ Sci 30:337-341

Shoda M (2017) Nitrification and denitrification, chapter 3: heterotrophic nitrification and aerobic denitrification by Alcaligenes faecalis No. 4. InTech, Rijeka, Croatia. https://doi.org/10.5772/68052

Sun XM, Li QF, Zhang Y, Liu HD, Zhao J, Qu KM (2012) Phylogenetic analysis and nitrogen removal characteristics of a heterotrophic nitrifying-aerobic denitrifying bacteria strain from marine environment. Acta Microbiol Sin 52:687-695

Sun HF, Wang HW, Yuan CY (2013) Optimization of zinc-cadmium reduction method for determination of nitrate in seawater. Adv Mater Res 864-867:1004-1007. https://doi.org/10.4028/www. scientific.net/AMR.864-867.1004. Accessed Nov 2014

Szeto SSW, Reinke SN, Sykes BD, Lemire BD (2007) Ubiquinonebinding site mutations in the Saccharomyces cerevisiae succinate dehydrogenase generate superoxide and lead to the accumulation of succinate. J Biol Chem 282:27518-27526. https://doi.org/10. 1074/jbc.M700601200

Tavares P, Pereira AS, Moura JJG, Moura I (2006) Metalloenzymes of the denitrification pathway. J Inorg Biochem 100:2087-2100. https:// doi.org/10.1016/j.jinorgbio.2006.09.003

Uygur A, Karg1 F (2004) Salt inhibition on biological nutrient removal from saline wastewater in a sequencing batch reactor. Enzym Microb Technol 34:313-318. https://doi.org/10.1016/j.enzmictec. 2003.11.010

Valdivia A, Pérez-Álvarez S, Aroca-Aguilar JD, Ikuta I, Jordán J (2009) Superoxide dismutases: a physiopharmacological update. J Physiol Biochem 65:195-208. https://doi.org/10.1007/BF03179070

Vyrides I, Stuckey DC (2009) Adaptation of anaerobic biomass to saline conditions: role of compatible solutes and extracellular polysaccharides. Enzym Microb Technol 44:46-51. https://doi.org/10.1016/j. enzmictec.2008.09.008

Wang T, Li J, Zhang LH, Yu Y, Zhu YM (2017) Simultaneous heterotrophic nitrification and aerobic denitrification at high concentrations of $\mathrm{NaCl}$ and ammonia nitrogen by Halomonas bacteria. Water Sci Technol 76:386-395. https://doi.org/10.2166/wst.2017.214
Wolińska A, Stępniewska Z (2012) Biochemistry, genetics and molecular biology, dehydrogenases, chapter 8 dehydrogenase activity in the soil environment. Rosa Angela Canuto. https://doi.org/10.5772/ 48294

Wu DH, You H, Zhang R, Chen C, Lee DJ (2011) Ballast waters treatment using $\mathrm{UV} / \mathrm{Ag}-\mathrm{TiO}_{2}+\mathrm{O}_{3}$ advanced oxidation process with Escherichia coli and Vibrio alginolyticus as indicator microorganisms. Chem Eng J 174:714-718. https://doi.org/10.1016/j.cej.2011. 09.087

Yang CM, Cai WJ, Wu Q, Li JH (2012) Effects of saltwater incursion on the microbiological characteristics and denitrification in a riparian rhizosphere soil in Chongming Island of Shanghai, East China. Chin J Appl Ecol 23:1083-1089. https://doi.org/10.13287/j.1001-9332. 2012.0147

Yin J, Chen JC, Wu Q, Chen GQ (2015) Halophiles, coming stars for industrial biotechnology. Biotechnol Adv 33:1433-1442. https:// doi.org/10.1016/j.biotechadv.2014.10.008

Zhang LH, Lang YJ, Wang CX, Nagata S (2008) Promoting effect of compatible solute ectoine on the ethanol fermentation by Zymomonas mobilis CICC10232. Process Biochem 43:642-646. https://doi.org/10.1016/j.procbio.2008.02.003

Zhang LH, Lang YJ, Nagata S (2009) Efficient production of ectoine using ectoine-excreting strain. Extremophiles 13:717-724. https:// doi.org/10.1007/s00792-009-0262-2

Zhang QL, Liu Y, Ai GM, Miao LL, Zheng HY, Liu ZP (2012) The characteristics of a novel heterotrophic nitrificationaerobic denitrification bacterium, Bacillus methylotrophicus strain L7. Bioresour Technol 108:35-44

Zhang SM, Li WG, Zhang DY, Huang XF, Qin W, Gu J (2015) Purification and characterization of a low-temperature ammonia monooxygenase from heterotrophic nitrifier Acinetobacter sp. Y16. Desalin Water Treat 53:257-262. https://doi.org/10.1080/ 19443994.2013.837002

Publisher's note Springer Nature remains neutral with regard to jurisdictional claims in published maps and institutional affiliations. 